\author{
Michał Niebylski \\ University of Opole, (Poland) \\ The Institute of Political Science and Administration \\ e-mail: mniebylski@uni.opole.pl \\ ORCID: https://orcid.org/0000-0003-1623-5886
}

\title{
The Issue of Ideological Changes in the Context of the Polish Political Parties - Theoretical Models and Their Exemplifications
}

\begin{abstract}
The article aims to present and discuss five theoretical models explaining the issue of ideological changes in Polish political parties. The paper is to shed light on an ideology's dynamic nature and the process of building ideology in the political parties' environment. The article features a discussion on the circumstances favoring the implementation of ideological changes and the methods used by parties to implement changes in their ideologies. The paper adopts two research hypotheses: 1) party ideologies are developed and modified by political parties in response to the changing (social, political, economic) circumstances in the inter-party rivalry. 2) The process of ideological changes serves political parties to lead an effective inter-party rivalry. The paper establishes that the factors with scientifically documented impact on party behavior in ideological terms are as follows: electoral result (parties that achieved a result below their expectations are more eager to revise their ideologies), political competition's activity (parties react to ideological changes of their direct rivals), electorate preferences (political forces can change their approach in crucial issues to reflect the dominant views in their electorates) and acceptance of free-market principles by the main political actors. An analysis of Polish parties' behaviors and the gathered source material also demonstrates that the parties' inclination to implement ideological changes depends on organizational factors.
\end{abstract}

Keywords: political parties, ideologies, ideological change

\section{Introduction}

The issue of ideology does not attract the researchers' attention today as it did some decades ago. Political sciences are featuring an increasingly popular opinion that the processes defining the state of contemporary democracies include: realignment in terms of socio-political 
divisions (Dalton, Flanagan, 1984), dealignment of social bonds with political parties (Miedle, 2013), a decline in the socio-structural factors' ability to affect individual voter decisions, development of alternative forms of collective activity (New Politics) (Dalton, Scarrow, 2004) and the emergence of the so-called floating voters (Gray, Caul, 2000). The changes taking place in contemporary democracies are deemed as evidence for the depreciation of the significance of ideology and a decline in its impact on political processes. Researchers are becoming convinced that developed democracies entered the post-ideological stage characterized by founding politics on evidence, knowledge, and not ideological assumptions (Bell, 2000). The development of meritocracy, technocracy, and professionalization of politics create conditions in which the ideological dispute of competitive political visions is in decline (Crouch 2004).

The transformation of contemporary democracies is related to political parties' changes, vital for indirect democracy mechanisms' functioning. To grasp and specify the changes, researchers dealing with political groups have constructed new party types to accentuate their dominant features. In political literature, it is possible to find a whole series of typological proposals, starting with a voter party (Kircheimer, 1966), through a cartel-type party (Katz, Mair, 1995) and ending with other, less known concepts (Lees-Marshment, 2001; Hopkin, Paulucci, 1999). All of the mentioned models share the assumption about the declining significance of ideology as a determinant for political parties' activity. At the same time, studies on political parties boosted new research notions related to political marketing and public relations or party leadership. The establishment of a new field of political studies has undoubtedly rekindled this scientific discipline and contributed to the development of knowledge on political party activity, their functions in the political system, and mechanisms of gaining and maintaining power. For these reasons, the revaluation in political sciences must be deemed positively. On the other hand, it is impossible to be indifferent to disavowing the issue of ideology and its declining significance as the subject of political studies. There is a widespread opinion among researchers assuming that ideology is a relatively coherent system of ideas and assumptions, characterized by a high degree of generality and relative permanence (Leksykon politologii, 2004, pp. 134-135). The transposition of this approach to ideology to political parties often made researchers describe the ideological assumptions adopted by parties as if they were changeless and resistant to the passage of time or not subject to adjustments and revaluations. The parties, their leaders, and the implemented strategies could change, but the political actors' ideological identity remained unchanged. The relevant deliberations were based on a static view of ideology, and the parties were presented as organizations devoid of resources, competencies, and will to revise ideologies. Although a change in the party's attitude toward specific social, economic, or political problems was noted, this was not considered a phenomenon pointing to an ideological revision but was instead explained as tactical matters.

Meanwhile, even a brief observation of the political actors' behavior could bring the conclusion that from election to election, most parties present new ideas, concepts and are 
often critical of the earlier postulated solutions. During an election campaign, the given party mainly emphasizes its economic programme, and in the next campaign, it speaks of social problems or focuses on international affairs. It uses benign political language one time just to take a more aggressive approach to social and political topics on another occasion. When in the opposition, it is critical toward the social and political reality and becomes a defender of the existing state of affairs after regaining power.

For supporters of the politics' de-ideologization thesis, this will be damning evidence of the party's lack of ideology, the domination of opportunism, pragmatism, and social engineering. However, looking at the conditions in which cross-party competition takes place (including, among others, social heterogeneity, multiplication of social interests and requests, weak ties between parties and their electorates, voter instability) and treating party ideologies as a resource used by political actors to achieve their goals, it is necessary to assume that party variation in terms of programmes, behaviors, and narrations proves that the ideological plane is still vital for the party and it features dynamic processes demonstrating the reactions of political actors to the changes taking place in their internal and external environments.

The purpose of this paper is to obtain answers to the following research questions:

1. For what purpose do political parties introduce ideological changes?

2. What factors contribute to the initiation of ideological changes in political parties?

3. In what manner does the intra-party environment affect the inclination to introduce ideological changes?

4. Is the introduction of ideological changes favorable for political parties? If so, what are the benefits of such action?

The paper adopted two research hypotheses:

1. Political parties develop and modify ideologies in response to the changing (social, political, economic) circumstances in the inter-party rivalry.

2. The process of ideological changes serves political parties to lead an effective interparty rivalry.

In political science literature, there were various attempts at unfolding the issue of ideological changes. Generally speaking, we can distinguish five dominant theoretical models.

- electoral result model,

- competitive environment model,

- social preferences model,

- neo-liberal convergence model,

- organizational structure model. 


\section{Electoral Result Model}

The past election model developed by Ian Budge envisages that parties change their ideological positions in the same direction as in the last election if they achieved a favorable electoral result and in the opposite direction if the result was worse than anticipated (Budge, 1994, p. 450). From the point of view of party elites, extrapolation of the previous election results can be problematic due to the dynamic political situation and context of the election process itself. Despite the identified limitations, I. Budge deems it as a more reliable source of information that can be used by political actors.

According to Zeynep Somer-Topcu's findings, parties that lost approval in the election are more willing to revise their ideology and modify their programme priorities and introduce a risky political strategy. On the other hand, parties with electoral income tend to "stay in place", i.e. continue their earlier course according to the message "if it works, don't change it" (Somer-Topcu, 2009, p. 246). Z. Somer-Topcu's studies also show that the impact of earlier elections diminishes over time. The optimal time for initiating the process of widely understood changes is several months after the election. I. Budge's and Z. Somer-Topcu's study results correspond to the observations of Robert Harmel and Kenneth Janda. They note that an ideological change in parties takes place due to various external shocks (Harmel, Janda, 1994, p. 269). They view an election loss as one of the most decisive impulses stimulating the commencement of various remedial action in parties (including, among others, redefinition of the party ideology) ${ }^{1}$.

The model emphasizing election results in explaining ideological changes was criticized for its insufficient explanatory potential. In Gijs Schumacher's, Catherine E. de Vries's, and Barbara Vis's opinion, the factor contributing to party transformation is not the election result itself, but how the party organization reacts to this result (Schumacher, de Vries, Vis, 2010, p. 5). The center of gravity is therefore put on the internal mechanisms of making political decisions. The problem with this model was also shown in a different light. Kris Deschouwer stated that an election loss may be deemed as a stimulus for commencing changes only when the party organization's list of potential goals is reduced to a single item, i.e. defeating the competitors in the election rivalry (Deschouwer, 1992, p. 9). However, this occurs at the cost of other goals, which can be of equal importance for various types of parties (e.g. affecting politics in a manner compliant with ideological principles). Some empirical studies questioned the relevance of the election result (Adams, Clark, Ezrow, Glasgow,

${ }^{1}$ In R. Harmel's, U. Heo's and K. Janda's opinion (1995, pp. 1-33), party functioning depends on both the party's internal surroundings and the external context. Aside from losing electoral support, other external stimuli affecting a political party can be the loss of the ruling party status (transition into the opposition in effect) or a crucial event in the international arena (e.g. Soviet empire collapse). The most important finding of Harmel and Janda is the statement that parties respond to various stimuli depending on the primary goals they are planning to achieve. 
2004). Another weakness of this model is the exaggeration of the lack of party access to reliable information about the current electoral preferences and developing tendencies in society. Thanks to co-operation with public opinion research centers utilizing state-of-the-art research methods and techniques, it seems that this problem lost its relevance. Currently, political parties receive reliable and periodically updated data on their social support and the factors shaping it. Therefore, they can correct their ideological and programme offer on the fly without referring to election results.

However, observation of the Polish political scene allows for the conclusion that a bad electoral result was often a source of substantial political parties' ideological changes. For example: in 2005, the Civic Platform (Platforma Obywatelska - PO) lost the electoral rivalry with Law and Justice (Prawo i Sprawiedliwość - PiS). The post-election period did not bring a coalition between the parties (the so-called PO-PiS), despite both parties agreeing in many aspects (e.g. both were for de-communization, fighting against corruption) and represented a conservative approach to worldview issues. PO's loss started a series of ideological changes, which made the party the opposite of PiS and allowed it to win the early election two years later. On the other hand, an electoral win is perceived by parties as a signal that its party ideology is working and that the essential assumptions must not be changed. It is illustrated, among others, by PiS. In the parliamentary election of 2019, PiS maintained the most important programme postulates presented four years earlier.

\section{Competitive Environment Model}

The basis for this paradigm is the assumption that the ideological transformation occurring in parties is a reaction to the re-positioning of the main rivals in the political scene. This assumption implies both the specified concept of cross-party relations and certain suppositions concerning the political actors themselves. In terms of the first notion, it must be said that this model assumes a strict interdependence of the parties and viewing the relations between them as a factor that forms their programme offer. The second notion assumes that the party's positioning in the ideological space considers its competitors' position and anticipates their future moves (Laver, 1992, pp. 266-274).

Empirical evidence in favor of the thesis on the impact of the competitive environment on a party's ideological changes were collected and presented by J. Adams and Z. SomerTopcu (Adams, Somer-Topcu, 2009). Their studies, covering nearly two hundred parties in twenty-five democratic states, allowed for identifying two regularities. According to the first regularity, parties during assumption reconfiguration tend to recreate the same measures taken by their main rivals in the previous election (this phenomenon is known among researchers as a party dynamics result). It seems that we can deem the "third-way" concept as an illustration of this trend. It was implemented by the left-wing in the 1990s (by the SPD in Germany under the reign of chancellor Gerhard Schroeder, the Labor Party in Great Britain with Tony Blaire as prime minister and the Democratic Party in the USA 
during Bill Clinton's presidency, among others) to respond to multiple election wins of the right-wing representatives such as Helmut Kohl in Germany, Margaret Thatcher in Great Britain and Ronald Regan in the USA. In terms of ideology, the "third-way" was an attempt to synthesize liberal ideology with social democracy, which was an effective formula that allowed social democracy to recover from the ideological and political crisis (Zuba, 2010, p. 196). The application of this model allowed left-wing formations to prevent further election losses and regain power ${ }^{2}$. Simultaneously, it is necessary to note that the left-wing's election success contributed to the ideological transformation in right-wing formations, which developed their own "third-way" model, partially emulating the social democratic programme (McAnulla, 2010, pp. 286-314).

The second conclusion from J.Adams's and Z. Somer-Topcu's research was the observation that political actors are exceptionally responsive to the ideological transformation of rivals belonging to the same ideological family. The left-wing reacts to ideological changes of left-wing parties. In contrast, right-wing parties model their ideological profile in response to measures taken by formations representing the right-wing (researchers deem this trend as the ideological families result). This trend results from parties' striving to effectively compete for the support of similar electoral segments (Allen, 2009).

The contribution of a competitive environment to the occurrence of ideological changes in Polish parties was observable when looking at the dispute of PO and PiS on the Rodzina 500 plus programme and, more broadly - the scope of state protection over its citizens. Before the election of 2015, PiS presented an electoral concept assuming providing families with financial support, the level of which was to depend on the number of children (a monthly child benefit of PLN 500 was to be provided for each second and subsequent child in the family). Initially, PO was among the staunchest critics of this concept. The party pointed to the fact that state budgetary capacity does not allow for such far-reaching protection. It also emphasized the negative impact of PiS's vision on the labor market. PO envisaged that child benefits would discourage some parents from taking up occupational activity (which turned out to be accurate). The Rodzina 500 plus programme, started in April 2016, enjoyed tremendous public support. PO, seeing the public's reaction to Rodzina 500 plus, completely changed its approach to the programme. In public discourse, $\mathrm{PO}$ even started to present the view that the child benefit as part of the programme should also be provided for the first child $^{3}$. The pro-social ideological changes in PiS contributed to the analogous ideological transformation in PO.

2 In Jerzy Kornaś opinion (Kornaś, 2004, p. 299), the price paid by contemporary social democracy for survival in the political market was very high. A uniform political doctrine couldn't be formulated after rejecting Marxism as an ideological and theoretical basis. Left-wing views on the concept of state are varied and slightly exceed the "welfare state" social and liberal model.

3 At the beginning of July 2019, Mateusz Morawiecki's government broadened the programme's assumptions and today it is the main element of PiS's family policy. 


\section{Social Preferences Model}

In the social preferences model, it is possible to observe two types of research concepts: the common denominator of which is the belief that parties' ideological assumptions are a reflection of views typical for specific social groups. As a result, the determinant for the formation (and change) of a party's ideological profile is the widely understood social environment. The first concept will take the name of congruence orientation, which owes its theoretical and programme scheme to the paper of A. Downs titled An Economic Theory of Democracy (Downs, 1957). This concept emphasizes the dynamic relations between changing social preferences and moods and the content of political actors' ideological and programme offers. Specifically, transitions in the voters' ideological auto-identification imply a relocation of a party's position in the left wing-right wing axis and modification of the ideological basis. The second concept, we will name it the axiological concept, emphasizes value system transformation in initiating ideological transitions in political formations. This aspect was noted by R. Inglehart, who documented the crystallization of a new set of values in developed countries after World War II.

In A. Downs's opinion, the aspirations of formations are focused on winning elections. For this purpose, they adapt their party ideologies to the view sets dominating in society, whereas they mainly consider moderate voters' opinion (Downs, 1957, p. 142). It is assumed that rational voters will give their vote to parties with similar ideological stances. A change in social views must therefore cause specific ideological transformation in political parties. If parties did not react to social preference changes, there would be a dissonance between voter opinions and political actor opinions, and the voter support process would become substantially distorted. To describe the phenomenon in which parties react to public opinion changes, the research team lead by James Stimpson used the term "dynamic representation" (Stimson, MacKuen, Erikson, 1995, pp. 543-565).

The issue of relations between social preferences and a party's ideological changes attracted many researchers' attention, which allowed for empirical verification of the assumptions constituting the basis for A. Downs's theory. Research conducted by James Adams, Michael Clark, Lawrence Ezrow, and Garrett Glasgow demonstrated by formations do not tend to react to each change in public opinion. They generally react when the turn of events in society can adversely affect their receipt and last election chances. It concerns a situation in which right-wing formations correct their ideological positions under the pressure of left-leaning mood in society or when left-wing formations are transitioning toward the center to react to the greatest possible extent to the public opinion's lean toward the right-wing (researchers named this trend as dynamics of disadvantaged parties result) (Adams, Clark, Ezrow, Glasgow, 2004, p. 590). L. Ezrow drew similar conclusions in the latter research in which he analyzed the data derived from twelve Western European countries of 1976-1998 (Ezrow, 2007, p. 191). It is worth noting that the assertions specified in the described model were positively verified not only in the European context. In America, 
Robert S. Erikson, Michael B. Mackuen, James A. Stimson demonstrated the impact of public opinion fluctuation on ideological changes (Erikson, Mackuen, Stimson, 2002).

Based on the mentioned study results, it is possible to state that the collected empirical material strongly supports the congruence orientation. Therefore, let us look at the second concept, which deems social value transformation as the main determinant of ideological changes. The value transformation process identified by R. Inglehart put mainstream parties in a completely new situation. On the one hand, a new set of post-material values was constituted, which could structure electoral behaviors of a particular part of the electorate. On the other hand, new political initiatives were born (e.g. green parties) to utilize the rising niche in the political market. Adaptation to the mentioned changes required mainstream formations to introduce substantial ideological adjustments and take a position concerning an entire spectrum of new issues (environmental protection, multiculturalism, gender equality) which came into existence in the public discourse thanks to - as R. Inglehart put it - the "silent revolution" (Inglehart, 1965). As a result, both political sides' representatives commenced, to a various degree, ideological revaluation (Andersen, Bjørklund, 1990; Veugelers, 2000; Müller-Rommel, 1985). Therefore, in R. Inglehart's opinion, it is possible to state that party actors are responsive to the value sets forming in society, and it is the axiological conflict that is the primary stimulus for changes.

The social preferences model also became a hot topic of discussion among researchers. It was emphasized that the reaction to public opinion fluctuations is not a party's constant inclination, but rather depends mainly on organizational factors (party size, member structure, among others) (Ezrow, de Vries, Steenbergen, Edwards, 2011, pp. 275-301). Other studies confirmed that the degree of responsiveness to social preference changes depends on the party's position in the left-right wing axis (Adams, Haupt, Stoll, 2009, pp. 611-639).

There are many examples of parties introducing ideological changes in response to shifts in public opinion, and quite often, such changes regard vital issues. PO's approach to accepting refugees in Poland changed when many of its supporters started to express their skepticism toward such a solution (CBOS, 2016, p. 3). On the other hand, PiS corrected its approach to evaluating Poland's integration with the European Union before the accession referendum, along with the increasing pro-European attitudes in its electorate (CBOS, 2003, p. 4). The Polish People's Party (Polskie Stronnictwo Ludowe - PSL) made a similar move.

\section{Neo-Liberal Convergence Model}

The concept, according to which political actors react to economic processes occurring in the global economy, must be treated as a reflection of the theoretical trends in the neo-liberal convergence model. It assumes that parties' ideological change aims to accept neo-liberal solutions in economics and synchronize with them other ideological assumptions.

The neo-liberal convergence model assumes that the reservoir of acceptable methods of activity in the financial and economic sphere became radically limited on a domestic scale 
due to the financial system integration, international trade liberalization, capital mobility, and increase in relations between domestic economies (Andrews, 1994; Cerney, 1997; Strange, 1996). Due to the above, both the objectives and instruments of social and economic policies in particular countries are convergent. In other words, neo-liberal guidelines assuming, among others, market deregulation, tax rate reduction, limiting the state's role in stimulating economic processes, redefinition of the social policy principles are becoming the reference point for activities taken up by political actors in various democratic countries. It puts in doubt the autonomy of domestic politics and the ability of states to exercise effective control over the market processes.

Such conditions create specific implications for parties, their decision-making scope during governance, and ideological differences between left-wing and right-wing representatives. Suzanne Berger stated that "it is irrelevant whether it is the left or the right that wins the election; the limitation of internationalized economy obliges both sides to copy the same monetary and fiscal policies, otherwise they will face a loss of domestic economy competitiveness and investments" (Berger, 2000, p. 51). This conceptualization is based on the assumption that the macro-economic conditions prevent formations from displaying existing programme differences in the governance process. There is, however, a more radical view according to which globalization leads to homogenization of political markets and for ideologies, and their institutional representations, alternative to neo-liberalism to go out of date. In this sense, parties become similar to one another, leave their ideological positions, and generally more or less openly support market solutions ${ }^{4}$.

In political science literature, this issue was often referred to contemporary social democracy. Today, the prevailing opinion that traditionally understood social democracy opting for full employment and a high degree of public expenditure is currently in a severe crisis (Mishra, 1998, p. 482). As explained by Stuart Thompson, "the social democratic dilemma in a post-Ford economy is based on striving toward a fairer society as part of the capitalist system and liberal democracy, without infringing consumer choice or entrepreneurial initiatives. However, advanced capitalism leads to the disintegration of institutions required to realize the social democratic order. Without an alternative policy, with a weakened value system, social democratic parties must face an uncertain future" (Thomson, 2000, p. 1). In scientific discourse, it is emphasized that left-wing formations tend to absorb liberal solutions (Hay, 1999; Lavelle, 2007). An intensification of this trend was observed concerning the application

4 R. S. Katz and P. Mair (Katz, Mair, 2009, p. 754), based on observation of trends in the global economy, decided to revise some assumptions of the cartelisation concept by including in it the impact of international factors on the change in the nature of international interactions. These researchers came to the conclusion that European integration, transfer of control from national to the transnational level and economic systems' unification partially limit the field of political rivalry. Thus, these factors contribute to the blurring of ideological and programme differences between parties and facilitate the occurrence of co-operative behaviours in the political scene. 
of the "third-way" model in the political strategy of the left in Western Europe and the USA. A reaction to this turn was the announcement of the end of social democracy by some researchers (Lavelle, 2008; Gray, 1996).

The issue of the neo-liberal convergence model was illustrated in various ways. For example, Andrea B. Haupt, although she agreed with the thesis that global economic trends affect ideological projects developed by parties, was also critical about the model itself. She was convinced that its basis featured economic determinism, which narrows the analysis of political actors' behavior reconfiguration only to the impact of macro-economic factors. Consequently, other motivations that can potentially initiate the process of ideological changes are outside the margin of research (Haupt, 2009, p. 9). Furthermore, the model assumes a one-way pattern of a party's ideological orientation development. However, A. Haupt's research shows that formations react differently to the global economy's processes. Therefore, the political market homogeneity thesis is a misuse and misses the actual processes occurring in politics. Thereby, it is not possible to accept the neo-liberal ideas universalization thesis in terms of party ideologies. A. Haupt also opposes the trend of assigning left-wing formations with special susceptibility to the pressure of macro-economic factors. Her research demonstrates no substantial differences in responsiveness to these factors among the left-wing and right-wing representatives (Haupt, 2009, p. 19). The inadequacy of describing political reality in the neo-liberal convergence model was also illustrated in another manner. Geoffrey Garrett shows that the globalization phenomenon, contrary to conventional opinion, is not coupled with neo-liberalism's monopoly in the ideological spectrum. It also does not lead to the unification of the social and economic policies rules at the national level. On the contrary, despite the growth of globalization, the left-wing offer is gaining stature as an ideological and programme alternative for which there is substantial voter demand, partially because of the high social costs generated by globalization ${ }^{5}$. Moreover, as evidenced by the researcher, configuring the state's economic policy according to the left-wing programme results in improved economic indicators (Garrett, 1998, p. 1). Herbert Kitschelt and his team raised critical remarks against the neo-liberal convergence theory (Kitschelt, Lange, Marks, Stephens, 1999, pp. 440-441)6.

5 In G. Garrett's opinion (Garrett, 1998, p. 130), the left-wing social and economic policy is necessary due to its ability to reduce the negative effects of globalisation and fluctuations in global markets. The instruments of the left-wing alternative include the following: 1) redistribution, which to a degree nullifies social inequalities; 2) high public expenditure, which stimulates economic growth; 3) active social policy, which absorbs the fluctuation of economic processes; 4) encouraging employment and investment through creation of stable social, economic and political conditions.

6 Five reasons were deemed as key in this aspect: 1) competition's deficiency in international scale; 2) achieving various effects in the internationalisation of domestic economies; 3) different opinion on economic processes depending on the institutional context; 4) conditioning economic decisions on political 
The neo-liberal convergence model was also realized by the Democratic Left Alliance (Sojusz Lewicy Demokratycznej-SLD) in Poland after the won election of 2001. The then head of SLD, Leszek Miller, set the party on the development path taken by the Labor Party in Great Britain under T. Blair and the German social-democrats. SLD's revision of ideological assumptions mainly concerned its approach to a free-market economy. The party abandoned its attempts of building alternative forms of economy and instead started to support the market economy and implement reforms favoring fast economic growth (even if they were leading to rising social inequalities). L. Miller's party even announced support for introducing a flat-rate tax in Poland.

\section{Organizational Structure Model}

The exploration of the links between a party's organizational structure and the coherence of its ideological offer has grounded tradition in political science studies. M. Duverger, when conceptualizing the mass party model, showed the dependencies between the organizational profile and the significance of party ideologies (Duverger, 1954). O. Kirchheimer, when observing the entry of Western European countries in the post-war period into a new economic and technological development stage, noticed not only a change in the parties' organizational formula (the catch-all people's model) but also the consequences for the direction of ideological changes (Kirchheimer, 1966, pp. 177-201). R.S. Katz and P. Mair, when claiming the thesis that the fourth generation of political formations (cartel parties) was born, also emphasized the interdependence between a party's organizational structure and ideological profile (Katz, Mair, 1996, pp. 525-534).

Even though they emphasized the impact of changes in the organizational structure on the shape and degree of party ideology exhibition, the mentioned models did not analyze the process of ideological change itself. They only showed a statistical increase in the significance of ideology in mass parties (compared to personnel groups from the $19^{\text {th }}$ century) or its devaluation (O. Kirchheimer's, R.S. Katz's, and P. Mair's models). However, they contributed to the establishment of the theoretical model stating that it is the organizational factors that bear the answer to the question of why do parties change in terms of ideology.

Gijs Schumacher, Catherine E. de Vries, and Barbara Vis determined that the crucial variable, in terms of ideological changes, is whether a party is based on a strong party leadership or broad participation of party officials. In the first case, it is more prone to modify the ideological position in case of fluctuation of public preferences or loss of the ruling party status. In the second case, ideological adjustments are usually a reaction to specific shifts among the electoral clientele (Schumacher, de Vries, Vis, 2010, p. 23).

decisions; 5) various impact of international economic pressure on domestic politics depending on the configuration of political forces, activity of interest groups and a series of other variables. 
On the other hand, the research of the team lead by Lawrence Ezrow showed the significance of party size. Specifically, large mainstream parties more often modify their ideological positions in response to changing public opinion than small parties (including communist, green, radical parties), which are more ideologically consistent and do not concede easily to public preference fluctuations. They usually revise when there is a fundamental discrepancy between their positions and supporter expectations (Ezrow, de Vries, Steenbergen, Edwards, 2011, p. 276). As shown by R. Harmel and K. Janda, ideological transformations can also be triggered by power alternation in the party's leadership structures or upset of balance between party fractions (dominance of one group at the cost of marginalizing another) (Harmel, Janda, 1994, pp. 266-267).

In the last model, despite the reasonable assumption that there are organizational factors in a party's ideological reaction to external stimuli, at the same time, except for cases specified by R. Harmel and K. Janda (power alternation, a rivalry of party fractions), it is difficult to imagine the same organizational factors to evoke the process of ideological changes. The researchers conducting the studies pointed out that the perspective considering the impact of organizational structure is equally necessary and insufficient (Schumacher, de Vries, Vis, 2010,p. 2). For this reason, it must be supplemented with an analysis of external phenomena related to party organization.

The impact of organizational determinants on the party's inclination to make ideological changes is evident in the Polish political scene. PSL is an example of a niche party demonstrating restraint in terms of implementing ideological changes. It derives from the fact that the party's position in the parliamentary arena depends on the support of a specific electorate segment (farmers, residents of rural areas, and small towns). Even though PSL attempted to broaden its ideological sources (relying on Christian and democratic thought), its ideological core (neo-agrarianism) remains its main trademark. On the other hand, the biggest parties in the Polish political scene (PiS and PO) have made bold attempts at reassessing their ideologies. Since its establishment, PO has defined its identity as liberalconservative (liberal in an economic sense and conservative in worldview issues). The ideological changes implemented in 2003-2005 were aimed more at exhibiting conservatism to facilitate a possible co-operation in coalition with PiS. The failure of the PO-PiS project inclined PO's leaders to revise their ideological assumptions. The party shifted closer to the center of the ideological axis by limiting the exhibition of both economic liberalism and worldview conservatism. It also announced the arrival of the so-called post-politics era, in which political pragmatism displaces ideological coherence. After surrendering its power in 2015, the party is still adapting its ideology to the needs of leading an effective inter-party rivalry (it is currently closest to social liberalism). A wide range of ideological changes can also be seen in PiS's ideology. At the time of its establishment, PiS was a conservative party that emphasized its anti-communism. As a result of spreading the idea of the IV Republic of Poland and strongly denouncing economic liberalism, the party has significantly diverged from conservatism (in the European sense) and adopted a nationalist and populist position. 
After regaining power in 2015, Jarosław Kaczyński’s party has broadened its ideology with pro-social elements.

The impact of intra-organizational factors (change of leadership) on a party's ideology is visible in SLD. With L. Miller as its leader, the party implemented the "third-way" assumptions by combining economic liberalism with a left-leaning view on social policy. The short period of leadership of Krzysztof Janik and Józef Oleksy could not have left a significant mark on SLD's ideology. Still, both men attempted to bring back the left-wing traditions in SLD and distance themselves from the "third-way" model. Electing Wojciech Olejniczak to SLD's leader had far-reaching political and ideological consequences. SLD attempted to build a broad settlement of left-wing, center-left, and center forces, which affected the Left and Democrats coalition (with the participation of the Democratic Party and the Polish Social Democracy, among others). SLD's ideology was largely subordinated to the new political project. It included the abandonment of the distinct left-leaning identity. The election of Grzegorz Napieralski for SLD's new leader started further ideological changes in the party. Under G. Napieralski's leadership, SLD became radicalized in the ideological sense, drawing inspiration from the Spanish Socialist Workers' Party lead at the time by José Luis Rodríguez Zapatero. The Zapaterism in SLD manifested itself in postulating tax increases for the richest, protecting the rights of minorities (including sexual minorities), and fighting against the Polish Catholic Church's privileges. L. Miller's return as SLD's leader caused a shift to social and liberal positions. Włodzimierz Czarzasty is SLD's current leader. The party underwent significant ideological changes in recent years. It seems that it deems material values (e.g. social justice) and post-material values (protection of the rights of sexual minorities, ecology) equally important. It is possible to state that SLD is gradually evolving toward the new left.

\section{Summary}

The conducted analyses demonstrate that contemporary political parties in Poland make ideological changes very often. It is challenging to specify a relevant party in the Polish parliamentary arena that refuses to correct its ideological assumptions for a more extended period. The dominant behavior model among parties is the adaptation of party ideologies to the dynamically changing social, political, or economic circumstances. It was established in this paper that the factors with scientifically documented impact on party behavior in ideological terms are as follows: electoral result (parties that achieved a result below their expectations are more eager to revise their ideologies), political competition's activity (parties react to ideological changes of their direct rivals), electorate preferences (political forces can change their approach in key issues to reflect the dominant views in their electorates) and acceptance of free-market principles by the main political actors. An analysis of Polish parties' behaviors and the gathered source material also demonstrates that the parties' inclination to implement ideological changes depends on organizational factors. A broader 
range of ideological changes usually is implemented by bigger parties, whereas niche parties, representing a specific voter segment, remain more reserved in this regard. It was also demonstrated that changes in party leadership are related to more frequent revisions of ideological assumptions. Based on the above findings, it is possible to verify the research hypotheses adopted in the paper positively.

Based on the deliberations included in this paper, it is possible to specify four main objectives for implementing ideological changes by parties. The first objective is quite obvious and assumes the maximization of electoral gains. Therefore, the revision of party ideologies becomes part of activity aimed at gaining higher electoral support. When taking part in the parliamentary election of 2001, SLD adopted a moderate message in terms of worldview issues to avoid a conflict with the Catholic Church and losing several percent of the votes as a result of this conflict. The second objective of ideological changes is the avoidance of harmful stereotypes. PO's reaction to PIS's activity aimed at developing a dichotomy of a solidary and liberal Poland (in which PO's liberalism was equated with the elite's ideology, for the elite) was to distance itself from the most controversial liberal ideas (e.g. the flat-rate tax). The third objective of ideological changes is the search for a new market niche. It means that parties use ideological changes to position themselves in the political market from scratch and find the support of broader electorate circles. It was the objective of PSL, which was led by Janusz Wojciechowski in 2004-2005. Under his leadership, the party tried to transform into a Christian Democrat and Peoples' party that would win over residents of rural areas and urban areas. There are also cases when political actors make ideological changes to redeem themselves and regain lost public trust. It was SLD's objective when it took up remedies after losing power in 2005. The public was critical of the party's achievements in 2001-2005, especially its passiveness in eliminating social inequalities and deemed it an error to focus on economic growth at the weakest groups' cost. SLD's redemption was supposed to introduce ideological changes attesting to placing greater emphasis on the concept of social justice.

Finally, it is necessary to answer whether the introduction of ideological changes is favorable for political actors. First of all, it should be noted that the implementation of ideological changes takes place in extremely disadvantageous circumstances and carries a lot of risks. These circumstances are characterized by an informational deficit in terms of the voters' expectations and the rivals' current strategies and the limited possibility of predicting the future situation and the requirements related to conducting an effective party rivalry. The circumstances substantially hinder the assessment of the impact of ideological decisions on the future political situation and the electorate's response. Despite this, parties take the risk and adapt their ideologies to the changing circumstances. It is possible to provide many examples demonstrating that ideological changes brought parties the expected gains. Thanks to its moderate approach to worldview issues, SLD did not waste its opportunity to win the election in 2001. By abandoning the most controversial programme ideas and implementing pro-social solutions, PO nullified the division into solidary Poland and liberal Poland. Today, 
this is not the central dispute point to structure the political rivalry in Poland. However, in many cases, the implementation of ideological changes did not achieve the assumed objectives. The revision of PSL's ideological identity, relying on a stronger emphasis of the Christian and Democratic thought in 2004-2005, did not enable the party to gain the support of a new electorate segment. SLD's attempt to regain the public's trust by returning to left-leaning values and ideas in 2005 was unsuccessful. The statement that the effectiveness of ideological changes depends on two variables - the scope of changes (an extensive scope of ideological changes bears the risk of disrupting the party's growth continuity) and the time of introducing the changes (delayed reaction to the changing circumstances can negate all effort made in the implementation of changes) seems to be justified.

\section{References:}

Antoszewski, A., Herbut, R. (2004). Leksykon politologii. Wrocław: Alta 2.

Adams, J., Clark, M., Ezrow, L., \& Glasgow, G. (2004). "Understanding Change and Stability in Party Ideologies: Do Parties Respond to Public Opinion or to Past Election Results?". British Journal of Political Science, 34, 589-610.

Adams, J., Haupt, A.B., Stoll, H. (2008). "What Moves Parties?: The Role of Public Opinion and Global Economic Conditions in Western Europe". Comparative Political Studies, 42, 611-639.

Adams, J., Somer-Topcu, Z. (2009). "Policy Adjustment by Parties in Response to Rival Parties' Policy Shifts: Spatial Theory and the Dynamics of Party Competition in Twenty-Five Post-War Democracies". British Journal of Political Science, 39, 825-846.

Allen, Ch.S. (2009). "Empty Nets. Social Democracy and the 'Catch-All Party Thesis' in Germany and Sweden". Party Politics, 15, 635-653.

Andersen, J.G., Bjørklund, T. (1990). "Structural Change and New Cleavages: The Progress Parties in Denmark and Norway”. Acta Sociologica, 33, 195-217.

Andrews, D.M. (1994). "Capital Mobility and State Autonomy". International Studies Quarterly, 38, 193-218.

Bell, D. (2000). The End of Ideology: On the Exhaustion of Political Ideas in the Fifties. New York: Harvard University Press.

Budge, I. (1994). "A New Theory of Party Competition: Uncertainty, Ideology and Policy Equilibria Viewed Comparatively and Temporally". British Journal of Political Science, 24, 443-467.

CBOS. (2003). Poparcie dla integracji z Unią Europejską, Komunikat z Badań, BS/46/2003 Warsaw, March. CBOS. (2016). Stosunek do przyjmowania uchodźców, Komunikat z Badań nr 111/2016, Warsaw, July.

Cerney, P.G. (1997)."Paradoxes of the Competition State: The Dynamics of Political Globalization". Government and Opposition, 36, 251-274.

Coole, R. (1994). "The Vulnerability of the Modern Cadre Party in the Netherlands". In: R.S. Katz, P. Mair (Eds.) How Parties Organize: Change and Adaptation in Party Organizations in Western Democracies (278-303). London: SAGE Publications Ltd.

Crouch, C. (2004). Post-democracy. Cambridge: Polity.

Dalton, R.J., Flanagan, S.C. (1984). "Parties under stress: Realignment and dealignment in advanced industrial societies". West European Politics, 7, 7-23. 
Dalton, R.J., Scarrow, S.E., \& Cain, B.E. (2004). "Advanced Democracies and the New Politics". Journal of Democracy, 15, 129-137.

Deschouwer, K. (1992). “The Survival of the Fittest: Measuring and Explaining Adaptation and Change of Political Parties". Paper Presented at the Workshop on Democracies and the Organization of Political Parties, European Consortium for Political Research. Limerick, Ireland. Erikson, R.S., Mackuen, M.B., Stimson, J.A. (2002). The macro polity. Cambridge: Cambridge University Press.

Ezrow, L. (2007). “The Variance Matters: How Party Systems Represent the Preferences of Voters”. The Journal of Politics, 69, 182-192.

Ezrow, L., de Vries, C., Steenbergen, M., \& Edwards, E. (2011). "Mean voter representation and partisan constituency representation: Do parties respond to the mean voter position or to their supporters?". Party Politics, 17, 275-301.

Franklin, M.N. (2004). Voter Turnout and the Dynamics of Electoral Competition in Established Democracies since 1945. Cambridge: Cambridge University Press.

Garrett, G. (1998). Partisan Politics in the Global Economy. Cambridge: Cambridge University Press. Gray, J. (1996). After Social Democracy. Politics, capitalism and the common life. London: Demos.

Gray, M., Caul, M. (2000). "Declining voter turnout in advanced industrial democracies, 1950 to 1997: The effects of declining group mobilization”. Comparative Political Studies, 33, 1091-1122.

Gunther, R., Mughan, A. (1993). “Political institutions and cleavage management”. In: R.K. Weaver, B.A. Rockman (Eds.), Do institutions matter? Government capabilities in the United States and abroad (272-301). Washington: Brookings Institution Press.

Harmel, R., Heo, U., Tan, A., Janda, K. (1995). "Performance, Leadership, Factions and Party Change: An Empirical Analysis”. West European Politics, 18, 1-33.

Harmel, R., Janda, K. (1994). “An Integrated Theory of Party Goals and Party Change”. JournalofTheoretical Politics, 6, 259-287.

Hay, C. (1999), The Political Economy of New Labour: Labouring Under False Pretences?. Manchester: Manchester University Press.

Hopkin, J., Paolucci, C. (1999). "The business firm model of party organisation: cases from Spain and Italy”. European Journal of Political Research, 35, 307-339.

Inglehart, R. (1971). “The Silent Revolution in Europe: Intergenerational Change in Post Industrial Societies”. The American Political Science Review, 65, 991-1017.

Janda, K., Harmel, R., Edens, C., \& Goff, P. (1995). “Changes in Party Identity. Evidence from Party Manifestos". Party Politics, 1, 171-196.

Katz, R.S., Mair, P. (1996). “Cadre, Catch-All or Cartel? A Rejoinder”. Party Politics, 2, 525-534.

Katz, P., Mair, R.S. (1995). “Changing Models of Party Organization and Party Democracy. The Emergence of the Cartel Party”. Party Politics, 1, 5-25.

Kirchheimer, O. (1966). “The Transformation of the Western European Party System”. In J. Lapolombara, M. Weiner (Eds.), Political Parties and Political Development (pp. 177-201). Princeton-New Jersey: Princeton University Press.

Kitschelt, H., Lange, P., Marks, G., \& Stephens, J.D. (1999). “Conclusion: Convergence and Divergence in Advanced Capitalist Democracies”. In H. Kitschelt, P. Lange, G. Marks \& J.D. Stephens (Eds.), Continuity and Change in Contemporary Capitalism. Cambridge: Cambridge University Press.

Kornaś, J. (2004). “Myśl państwowa polskiej socjaldemokracji”. In T. Ślęzak, M. Śliwa (Eds.), Polska lewica w XX wieku. Historia-ludzie-idee. Kraków: Wyd. Naukowe Akademii Pedagogicznej.

Lavelle, A. (2007). “Social Democracy or Neoliberalism? The Cases of Germany and Sweden”. In G. Curran, 
E. van Acker (Eds.), Globalising Government Business Relations (117-144). Frenchs Forest: Pearson Education Australia.

Lavelle, A. (2008). The Death of Social Democracy. Political Consequences in $21^{\text {st }}$ Century, Aldershot: Routledge.

Laver, M. (2005). "Policy and the Dynamics of Political Competition”. American Political Science Review, 99, 266-274.

Lees-Marshment, J. (2001). “The Marriage of Politics and Marketing”. Political Studies”. 49, 692-713.

McAnulla, S. (2010). "Heirs to Blair's Third Way? David Cameron's Triangulating Conservatism”. British Politics, 5, 286-314.

Mishra, R. (1998). “Beyond the Nation State: Social Policy in an Age of Globalization”. Social Policy Administration, 5, 481-500.

Mjedle, H.L. (2013). "How and Why Parties Respond to Membership Decline: The Case of the SPD and the CDU”. German Politics, 22, 253-269.

Müller-Rommel, F. (1985). “The Greens in Western Europe: Similar but Different”. International Political Science Review, 6, 483-499.

Schumacher, G., de Vries, C.E., \& Vis, B. (2010). "Why Political Parties Change Their Positions: Environmental Incentives \& Party Organization", Paper Prepared for the $68^{\text {th }}$ MidWest Political Science Association (MPSA) National Conference. Chicago.

Somer-Topcu, Z. (2009). "Timely Decisions: The Effects of Past National Elections on Party Policy Change”. The Journal of Politics, 71, 238-248.

Stimson, J., MacKuen, M., \& Erikson, R. (1995). “Dynamic Representation”. American Political Science Review, 89, 543-565.

Strange, S. (1996). The Retreat of the State: The Diffusion of Power in the World Economy, Cambridge: Cambridge University Press.

Thomson, S. (2000). The Social Democratic Dilemma: Ideology, Governance and Globalization. New York: Palgrave Macmillan UK.

Veugelers, J.W.P. (2000). “Right-Wing Extremism in Contemporary France: A “Silent Counterrevolution”?””. The Sociological Quarterly, 41, 19-40.

Weakliem, D.L. (1991). “The Two Lefts? Occupation and Party Choice in France, Italy, and the Netherlands”. American Journal of Sociology, 96, 1327-1361.

Zuba, K. (2010). "Trzecia droga po 10 latach z perspektywy brytyjskiej i polskiej. Ślepa uliczna czy wyjście ewakuacyjne?". Studia Polityczne, 26, 195-213.

\section{Websites}

http://www.collinsdictionary.com/dictionary/english/dilemma?showCookiePolicytrue http://www.oxforddictionaries.com/definition/english/dilemma 